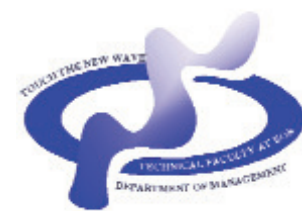

Serbian Journal of Management 13 (1) (2018) 7 - 28

www.sjm06.com

\title{
MODEL FOR INVESTMENT DECISION MAKING BY APPLYING THE MULTI-CRITERIA ANALYSIS METHOD
}

\author{
Adis Puška ${ }^{a *}$, Admir Beganovićb and Sead Šadićc

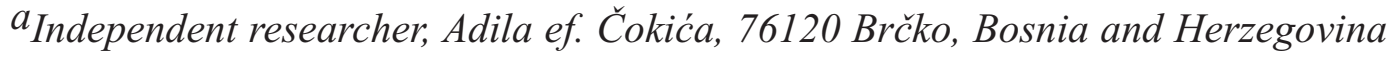

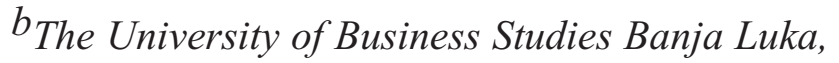 \\ Bosne Srebrne 76120 Brčko, Bosnia and Herzegovina, \\ ${ }^{c}$ PHI Health Center Brčko, Reisa Džemaludina Čauševića 1, \\ 76120 Brčko, Bosnia and Herzegovina
}

(Received 16 November 2016; accepted 19 May 2017)

\begin{abstract}
When making an investment decision the investor has got many alternative investment options available. The task of the investor is to choose one investment that will best accomplish the objectives of the investment project. In order for an investment to be possible, it is common practice to create a document that plans and especially outlines the form of the investment project. In order to choose an investment that best meets the goals of the project, it is necessary to evaluate the project. There are evaluation methods available for the investor to assess the effectiveness of an investment project. The results given by these methods are usually conflicting, thus causing difficulties for the investor's decision-making abilities.

This paper presents a model for improving the decision process in investment. The purpose of this model is to indicate the need for using methods such as the multi-criteria analysis method in order to evaluate the effectiveness of an investment. Due to the fact that the results of the evaluation methods are often different, it is necessary to take into account that there are a number of criteria that need to be acknowledged, in order to make the best investment decision. Multi-criteria analysis can be used to rank potential investment projects and enhances the decision-making process that is required to meet the goals of an investment.
\end{abstract}

Keywords: investment projects, making the investment decision, methods of multi-criteria analysis

\footnotetext{
* Corresponding author: adispuska@yahoo.com
}

DOI: $10.5937 / \mathrm{sjm} 13-12436$ 
8

\section{INTRODUCTION}

In contemporary society, the market changes are permanent. In order to improve its business, a company should meet the demands of its market (Ključnikov et al., 2016). Changing and improving a business is not possible without investment. That which a company invests today, could, in the future, achieve incomes that far surpass the initial investment. It is necessary to perceive an investment as a tactic that a company can use to fight the constant changes in the market.

When investing every company is faced with one of the most difficult decisions made in business and that is making the investment decision. Making the wrong decision on the implementation of certain investments may cause long-term catastrophic consequences for the company. Selection of investment is very difficult and requires considering many aspects.

The main problem in making investment decisions is that these decisions are made exclusively by management companies according to their own personal experiences or using their intuition. Often analytical and scientific methods that would help in making the right decision are not used. Therefore, the decisions made do not contribute to achieving the objectives of the company and often these decisions have negative consequences for the company.

Making investment decisions is crucial for any company because it represents a means of achieving the goals of companies that promote growth and development. Every company strives to develop and realize a greater profit. It is the profit that is the initiator for the investment.

The investment decision is not only a possibility, but the plan of company development, the choice of methods and modalities of work and everything else that is related to the business operations of the company. In any investment there is a certain risk, the level of risk depends on how detailed and well done the preparatory documentation is and whether the planned potential risk scenarios and responses to these scenarios are fully thought through.

Making the investment decision is the most important preparatory action in planning an investment. In making an investment decision, it is necessary to first define the ideas and then determine possible investment variants for the realization of these ideas, all of which must be consistent with the goals of the company.

Consideration of individual investment programs is done by using the method for assessing the effectiveness of investment projects. These methods are divided into two groups: static methods and dynamic methods. Static methods are often used in pre-investment studies because it is easy to calculate them. The disadvantage of these methods is that their results represent the realization of the investment within one year, which is called a representative year. Dynamic methods provide a complete assessment of the investment period and are not only representative of one year.

In the investment decision-making process, it is essential to exclude the subjective attitude of managers and instead include scientific and analytical methods based on multiple criteria for decision making as a support of final investment decision. It is then necessary to include as many methods of analysis as possible and objectively evaluate their importance in deciding whether to underwrite set development goals of the company. Since it is not always possible to make a single decision you need to compromise. Once that 
decision is made, the ranking of alternative options is performed through multi-criteria analysis.

However, in order to make decisions that will best realize or accomplish the objectives of investing it is necessary to compare the results with different investment alternatives. Therefore, this paper explores a model for making investment decisions which contribute to a more efficient decisionmaking process by using multi-criteria methods.

Numerous techniques and methods for making multicriteria decisions dealing with the issue of choosing projects have been developed in recent years. Mohanty (1992) used the method TOPSIS for solving the project-choice issue. He compared three construction projects with 15 criteria in India. Triantaphyllou and Mann (1995) applied the analytic hierarchy process (AHP) for choosing an information system project. Mohanty et al. (2005) used the analytic network process (ANP) for choosing projects. Kumar (2006) assessed and selected industrial investment projects using the AHP method. Mahmoodzadeh et al. (2007) applied AHP and TOPSIS methods for choosing projects. Amiri (2010), used AHP and fuzzy TOPSIS for selecting projects in oil development. The AHP method was used for the problem-structure analysis of project selection and for determining the difiicultiy of the criteria, while the TOPSIS method was used for final ranking. Manteghi and Haddadpour Jahromi (2012) used the AHP method for choosing between a current and a new project. Aragonés-Beltrán et.al (2014) applied AHP and ANP to develop a model that facilitates investors to choose projects suitable for investing. Pangsri (2015) applied MCDM techniques for choosing projects, based on
AHP and TOPSIS methods.

Having considered the above mentioned samples of using different MCDM methods for choosing projects, it can be concluded that different approaches exist and that therefore different MCDM methods can be used.

\section{THE EFFICIENCY OF THE INVESTMENT PROJECT}

Efficient investment evaluations are divided into static and dynamic evaluation methods for investment efficiency.

Static rating assesses the profitability of an investment project by implementing a budget of a number of so-called 'simple' static criteria. These criteria are calculated by taking into account the parameters from a single normal-year exploitation period (Jovanovic, 2006). As a standard or normal year within the exploitation period, i.e. as a representative year, Bendekovic (1993) considers that this year reflects or provides

- The maximum possible use of the project capacity is achieved;

- The project still has ongoing loan repayments.

This method of investment examination may offer a misleading picture, as it only takes into account a period of time rather than the entire economic life of the investment. These indicators do not follow the dynamics of investment. A particular disadvantage of this method of assessment is that it does not provide information on reducing the effects of investment in the initial and final time period of exploitation, and therefore offers no possibility of planning timely interventions and improvements (Nicin \& Pusara, 2010). In 
order to eliminate this problem of static indicators, the process of diminishing is performed. An acceleration of static indicators involves discounting the individual annual costs and effects of investments (income, expenses, and total investments) to the present value, or calculating the average annual value for the entire economic life of the project.

These methods are also divided into

- Methods that do not use discounted cash flows (NDCF techniques);

- Methods that use discounted cash flows (DCF techniques).

Decision makers are unable to reach maximum shareholder value by using NCDF techniques because these methods do not combine or fulfill all three basic conditions for these (Volarevic \& Davosir Pongrac, 2010b). The disadvantage is that they do not include the discount factor in the calculation, and therefore do not assess any risk related to future cash flows.

The methods that do not use the discount cash flows include the following indicators:

- Payback period;

- Accounting rate of return;

- Cumulative cash flows;

- The rate of return.

Payback period (PBP) is the time it takes to return the initial investment costs (Vernimmen, et al, 2009). Ehrhardt and Brigham (2011) define the payback period as the number of years required to repay for funds invested in the project, which is generated from its cash flows. Van Horne and Wachowich (2002) define that the payback period indicates the number of years required to repay the initial investment money. The process of calculating this indicator is done by cumulatively gathering net cash flows and determining the period in which or when the cumulative net cash flows are positive.

The main drawback of the method is that PBP does not consider the time value of money and the cash flows that occur after a fixed time of return. For this reason, this method is purely a subjective method and is to be taken as a supplement to other methods.

The accounting rate of return (ARR), represents the ratio of the average value of all future accounting net gains (losses) of companies, during the life of the investment project and the total value of an investment made in the same period (Viducic, 2006). The average value is obtained by adding up all the accounting gains / losses and shares, with the number of years.

In order to make a decision by this indicator, it is necessary to determine how the target rate of return (TRR) is expected. The following example shows this:

- $\quad$ ARR > TRR - the project is efficient;

- $\quad A R R=T R R-$ the project is neutral;

- $\mathrm{ARR}<\mathrm{TRR}$ - the project is ineffective.

Unlike other indicators, RDA does not include a category of accounting net income / loss in its calculation of future net cash. The disadvantages of using the RDA are the following (Ross et al., 2002):

- Does not use the rate of return, and ignores the time value of money;

- Uses an arbitrary reference threshold value;

- Uses the accounting value rather than market value and cash flows.

The cumulative cash flows (CCF) represent the final sum of cumulative future cash flows for an investment project in its last year of a lifetime (Volarevic \& Davosir Pongrac, 2010b). Here is an absolute 
measure of the efficiency of the project:

- $\quad \mathrm{CCF}>0$ - the project is efficient;

- $\quad \mathrm{CCF}=0$ - the project is neutral;

- $\mathrm{CCF}<0$ - the project is ineffective.

The upside of this method is the ease of computation, due to the fact that it uses cash flows of the entire economic life of the project and not as a method of PBP to breakeven. Since this method uses the absolute value of its use, investors should always use it alongside other methods and never rely on it alone.

The rate of return (ROR) is also known as return on investment (ROI) or in other literature can be labelled as the rate of profit which is the percentage of net profit after tax from investments undertaken to achieve this profit. It is calculated in this way by the arrival of deducting costs, and this amount is divided by the total cost of investment. The higher the amount that ROR is, the higher the return on investment is. When using this indicator in the investment decision process, we choose the investment that produces the higher return on investment.

In addition to these four methods (which are classified into methods that do not use discounted cash flows), there are also further methods that are mentioned in scientific literature. Those methods involve an indication of discounted time of return, using the discount cash flows, but they are not classified as dynamic indicators or indicators used in discount cash flows.

The discount payback period (DPBP) is the time required to recover the original investment using discount future net cash flows? It is calculated by first doing the discount value of cash flows, then the form of their cumulative value, and determines the year in which the cumulative discount cash flows are positive. As for the decision on the basis of this indicator, one uses the same rules as for indicators of time of return.

The question is whether this indicator should be included in the dynamic methods of evaluation of the efficiency of the project. The reason is that it does not use the net cash flows of the entire economic life of the project, but only those streams to which the refund of the initial investment is done. Based on this, it only uses a portion of the net cash flows (Puska, 2012).

Because it cannot be classified as dynamic methods it is often not applied in practice, but it represents only a means to eliminate those projects which do not have a payback within their economic lifetime of the project.

The methods used in the discount cash flows include the following methods:

- The net present value;

- Internal rate of return;

- The modified internal rate of return;

- Profitability index.

Dynamic indicators are more complex indicators in various ways, (including investments and the effects of investments) and also allow much more realistic analysis of different aspects of the investment project and of the justification for its realization.

The dynamic assessment uses certain criteria for which calculated parameters are used from the entire period of the investment and the operation of the investment project. Used techniques include discounting the investments and the effects of the total period of investment and exploitation, and then calculating the dynamic indicators (Puska, 2011).

The Net Present Value (NPV) is the sum of all future net cash flows of an investment project reduced to present value using the discount technique which involves lessening 
the initial investment in the investment project.

If NPN is the net cash flow of the investment project in the $n$-th year, $r$ is the discount factor that uses discount rate and $n$ is the number of years in the economic life of the project and I0 initial expenditure and then this indicator can be presented as follows:

$N P V=\frac{N P_{1}}{r}+\frac{N P_{2}}{r^{2}}+\ldots+\frac{N P_{n}}{r^{n}}-I_{0}$

Abbreviated form:

$N P V=\left(\sum_{i=1}^{n} \frac{N P_{n}}{r^{n}}\right)-I_{0}$

NPV, as well as a criterion CCF, is an absolute measure of efficiency because it is expressed in monetary units and not in percentage. For the person who makes the investment decision criterion NPV has the following characteristics:

- $\quad$ NPV $>0$ - the project is efficient;

- $\quad \mathrm{NPV}=0$ - the project is neutral;

- $\quad$ NPV $<0$ - the project is ineffective.

Another way of expressing this indicator is that the project will be accepted if the present value of cash receipts greater than the present value of spending money (Van Horne \& Wachowich, 2002). When there are more investments available to investors they will accept an investment project, which has a maximum value of NPV.

Criterion NPV can be used as a unique criterion only in special cases (Nicin \& Pusara, 2010):

When a company is able to implement its projects and lend unlimited amounts of capital at a real interest rate;

- When a company has enough of its own resources to accomplish any project under consideration, and that is economically justified;

- When the most important effect for the company to achieve the implementation of the relevant investment project - is the total weight gain.

The biggest problem in the application of NPV criteria decision making represents the definition of the risk of future cash flows through the selection of discount rates, or the proper application of the cost of capital to reflect realistic situations i.e. market values at the time of calculation (Volarevic \& Davosir Pongrac, 2010a).

Indicator NPV usually can be "improved" in the following ways: by increasing the length of the period of working capital, increasing the time of investment (investment funds), reducing the amount of investment and a reduction in the discount rate (Puska, 2012).

The internal rate of return (IRR) can be defined as the discount rate at which the net present value is reduced to zero (Brigham \& Ehrhardt, 2008). Van Horne and Wachowich (2002) define the IRR as the discount rate that equates the present value of expected net cash flows with an initial expenditure of money. It is expressed by the formula IRR is the discount rate at which:

$$
N P V=\left(\sum_{i=1}^{n} \frac{N P_{n}}{r^{n}}\right)-I_{0}=0
$$

If the NPV is positive value it means that the rate of IRR is greater than the discount. The negative NPV means that the rate of IRR is less than the discount rate. Finding the rate at which the NPV is almost zero in the positive and negative sense, is the basic task of calculating IRR. For the investment decision maker, the decision criterion is as 
follows:

- $\quad$ IRR $>r_{\min }$ - project efficiently;

- $\quad$ IRR $=r_{\min }$ - neutral project;

- $\quad$ IRR $<r_{\min }-$ project inefficient.

Making an investment decision based on IRR will follow if the calculated IRR investments are higher than planned, or the minimum return rate of the project. When these two rates are equal, then the decision must be based on other criteria (Krcmar, 2002). Method IRR sometimes does not allow ranking of investment projects, whilst the NPV method still allows ranking.

IRR as an indicator has certain disadvantages such as:

- The result of the IRR show percentage rather than monetary value; (Fabozzi \& Drake, 2010)

- When we look at complex projects where there is more investment not only initially but also whilst the existence of multiple IRR is possible;

- IRR does not provide the ability to study a project completely independent of another; (Jeremic, 2008)

- Being a complicated calculation process for calculating the value of this criterion;

- Since the discount rate obtained a ruling from the equation, the IRR does not take into account the preferences of time;

- It causes difficulty when determining the minimum acceptable rate, and others. (Nicin \& Pusara, 2010)

Modified internal rate of return (MIRR) is similar to the IRR but uses a more realistic approach to defining processes Reinvestment (Fabozzi \& Peterson, 2003). MIRR is the rate that equates the discounted value of positive cash flow at the end of the economic life of a project in order to discount negative cash flow at the beginning of the period (Puska, 2012). For the project deliverer, the investment decision criteria for investing in calculating the MIRR are as follows:

- $\quad$ MIRR > r - project efficiently;

- $\quad$ MIRR $=r-$ project neutral;

- $\quad$ MIRR $<\mathrm{r}$ - ineffective project.

So here ' $r$ ' stands for rate of reinvestment. So the decision is the same as with the IRR only that instead of the minimum acceptable rate it uses reinvestment rate. The main advantage when using MIRR criteria for investment in relation to the IRR criterion is the fact that in this case there is no possibility of obtaining more than one value MIRR (Volarevic \& Davosir Pongrac, 2010a).

Profitability index (PI) is defined as the NPV of the project divided by the initial investment (Stanisic \& Stanojevic, 2005). Whilst Van Horne and Wachowich (2002) defined it as the ratio of the present value of net cash flows and the initial expenditure of money, PI is often called the benefit-cost ratio, because in fact it represents the ratio between the benefits of investing in investment and investment costs (Orsag, 2002). It is calculated by the following formula:

$$
\mathrm{PI}=\frac{\sum_{t=1}^{n} \frac{N P_{t}}{r^{t}}}{N P_{o}}
$$

For the deliverer of investment decision criterion for investments with indicators PI is as follows:

- $\quad$ PI $>1$ - the project is efficient;

- $\quad$ PI $=1$ - the project is neutral;

- $\quad$ PI $<1$ - the project is inefficient.

Although it shows a relative measure of the value of this criterion, the criteria are of 
less use for NPV. The reason is that the NPV tells whether to accept the project or not and expresses the absolute contribution that the project has made in relation to creating wealth for shareholders. In contrast, PI expresses only the relative profitability (Van Horne \& Wachowich, 2002).

If the two projects have the same value NPV then they need to use the PI because it makes sure that they still don't have the same amount of NPV with different initial investment (Puska, 2012). This will select the most efficient project that has the highest PI value.

\section{METHODS OF MULTI-CRITERIA ANALYSIS}

In making decisions you must first choose an investment goal, and then the criteria which are used to measure the level to which this goal is achieved. Once this has been set one must then select the most suitable project from the available investment option in order to reach the set goal of investing with the most potential. Decision-making usually means evaluating possible solutions or alternatives. When the evaluation is done in relation to one criterion, a solution that extremes target function a determined, and the process is referred to as one criteria optimization or just optimization (Srdevic, 2002).

However, in practice, the most commonly encountered tasks are the ones where investment alternatives are to be assessed by several different criteria, which make the problem much more complex. The main role of decision makers is "reflected not only in the final decision but also in defining the multi-criteria bases - a criteria for evaluating alternative system, the choice of preferential function, determining the relative importance of criteria and the appropriate settings, all in the sensitive phase in solving the problems of business decision-making (Radojicic \& Vesic, 2003).

Whether directly or indirectly, in the process of making a decision, an alternative form of the matrix and the criteria will be subjected to analysis and processing in order to generate a final result. When working solely with the multi-criteria analysis, there are several alternatives and criteria, some of which should be maximized and some minimized. These decisions are made in conditions that lead to conflict situations and therefore we must apply problem-solving instruments that are more flexible than the strictly mathematical techniques.

Any method of multi-criteria analysis is characterized by a specific selection criterion, which is why different methods applied to the same problem generally provide different results. Precisely because of these characteristics, those different methods give different results, the basic methods for performing multi-criteria analysis will now be presented, but in the application itself only one of them will be used, the one that shows the best results in the investment decision-making in relation to all.

\subsection{Simple additive methods}

Simple additive method (SAW) is probably the most popular and most used method of multi-criteria analysis, and it is also the easiest one to use. The result of SAW method is provided by adding weight to each criterion (Yoon, Hwang, 1995).

SAW method is a simple method that usually gives similar results to the so-called advanced methods. It is directly applicable to 
the decision-making matrix, and it consists of three steps:

- Normalization to achieve comparability;

- Application of the weight value criteria to normalized parameters;

- $\quad$ The addition of "difficult" parameters for each alternative (Srdevic, 2005).

The best value alternative is when SAW has the highest value.

\subsection{The TOPSIS method}

In 1981, Hwang and Yoon developed the TOPSIS method. It is based on the concept that the selected alternative should have the shortest distance starting from the positive ideal solution and the longest distance from the negative ideal solution ( $\mathrm{Lu}$, et al, 2007).

The basic logic of the method is to first define the ideal solutions and then negative ideal solutions. The optimum alternative is the one that is the closest to an ideal positive solution, i.e. the farthest from the negative ideal solution. Ranking alternatives are based on relative similarity to the ideal solution, thus avoiding a situation where the alternative has simultaneously the same distance from the ideal positive and negative ideal solution.

The ideal solution is defined by using the best rating value alternatives for each criterion; in contrary negative ideal solution represents the worst value of the rating alternatives. The terms "the best "and "the worst "are interpreted for each criterion separately, according to whether it comes down to maximization or minimization criteria (Srdevic, et al, 2002).

The process of calculating the TOPSIS method begins by forming a decision matrix and then applying the following steps:
- $\quad$ Step 1 Normalizing matrix.

- Step 2 Multiply normalized matrix weight coefficients.

- Step 3 Determination of ideal solutions.

- Step 4 Determination of the distance from the ideal alternative solutions.

- $\quad$ Step 5 Determination of the relative closeness to the ideal solution.

- $\quad$ Step 6 Ranking alternatives.

Alternatives are ranked by decreasing values. The best alternative is the one that is the closest to or even has the value of the number one; the other alternatives are ranked by decreasing values (Triantaphyllou, 2000).

It is believed that the lack of the original TOPSIS method in determining the ideal and non-ideal point because for their coordinates the attribute values are taken which can be maximum and minimum for each of the criteria. In practice, it is often the case that these values are not always ideal / non-ideal for highlighting criteria. Particularly interesting are the qualitative criteria when giving marks in a scale of values. Then it is necessary to reach a consensus on whether an ideal point is that which is the best available option or an attribute that can be reached regardless of the fact of whether there are any available alternatives (Bukumirovic \& Cupic, 2005). This is solved by a modification of the general form of the method that relates to the introduction of the ideal and non-ideal point.

\subsection{The VIKOR method}

The VIKOR method (multi-criteria compromise ranking) has been developed to such methodological grounds that the decision maker proposes alternatives that represent a compromise between aspiration 
and opportunity or a compromise between the different interests of the participants in the decision-making process.

A compromise solution is a possible solution that is the closest to the ideal solution and therefore represents a compromise of mutual concessions made between the alternatives. It is based on determining the narrower set of possible solutions at values approaching the "ideal point", i.e. reference point in the space of criterion function.

As with all methods, we will start with the general form of the problem (matrix of decision-making) and subsequently implement the following steps:

- Step 1 Determination of the maximum and minimum values of a given criteria.

- Step 2 Calculating pessimistic and expected solution

- Step 3 Calculation of compromise

- $\quad$ Step 4 Ranking alternatives.

The best choice is the alternative with the lowest point(s). The main ranking is the result of a compromise ranking alternative list and a compromise solution with a certain rate. VIKOR is a useful tool in a multicriteria decision-making, especially in a situation where the decision maker is not able or does not know how to express the weights of the individual criteria at the beginning of the design for matrix decision. The resulting compromise was accepted by the decision maker because it provides maximum utility and minimum regret. Solution compromise can be the basis for negotiations involving decision-makers and the tendency towards certain criteria and to determine the weight of this criterion.

\section{THE DECISION-MAKING INVESTMENT MODEL}

When making investment decision the investors have got many alternative investment options available by which they may seek to reduce the risks and uncertainty in their investment projects. The use of these options, i.e. methods and techniques, mainly depend on the decision-maker, since he chooses the technique(s) with which he tries to avoid the risks and uncertainties that investments can bring.

The investor is faced with many different possibilities for investment decisions. The investor's task is to analyze all the possibilities and to make a detailed investment proposal for it. Another problem that the investor faces is when there are several alternatives concerning only one activity. The task of investor is to examine all alternatives and select that which is the best fit. The third problem that the investor has to face with is the most challenging. This is the case where the investor is facing the problem of investment decision-making where there are several alternatives and each is linked to some other activity.

Decision-making is carried out if there are investment alternatives. If there is only one alternative, then making further decisions makes no sense because there are no more alternatives left and the process is completed. Therefore, we will assume that during the implementation of this decisionmaking investment model, there are a number of alternatives (n). In order to compare alternatives, different methods are used, while in practice the most frequently employed methods are the means for assessing the efficiency of investment. Therefore, these methods will be applied in this model. We will mark the number of these 
methods with "m". Based on this, we can observe that when it comes down to the investment decision, the decision maker is faced with a decision that has " $n$ " alternative and they are analyzed with the " $m$ " criteria.

If all methods give the same order for all alternatives, then there is no difference in their ranking and according to these criteria, a unique rank order for all the alternatives is received. Then it is possible to reach a unanimous decision and the decision-making process ends at this point. However, when there is a different rank alternative order for these different alternatives then it is not possible to reach a unanimous decision but it is necessary to adopt a compromise decision or the decision that best meets the objectives for decision-making.

Decision-making model consists of the following steps:

1. Determine the starting alternatives for investment decisions

2. The effectiveness of projects

3. Reduction of parameters for assessing the effectiveness of the project through correlation analysis

4. Ranking investment alternative through multi-criteria methods

\section{Decision making}

These steps are graphically presented in Figure 1.

By comparing the results of the method(s) for assessing the effectiveness of investment projects, very similar or the same results are obtained according to certain criteria. It is, therefore, necessary to reduce the number of criteria. It is necessary to reduce the criteria in order to decrease the impact of these and similar methods on a final decision. For this reason, it is necessary to use correlation analysis in order to determine interconnection method for assessing the effectiveness of the investment project. Based on the results of correlation analysis, the reduction criteria will be done and thus facilitate the decision-making process. Reduction of the criteria terminates or finishes step 3 and moves on to the next process given in step 4 in this model.

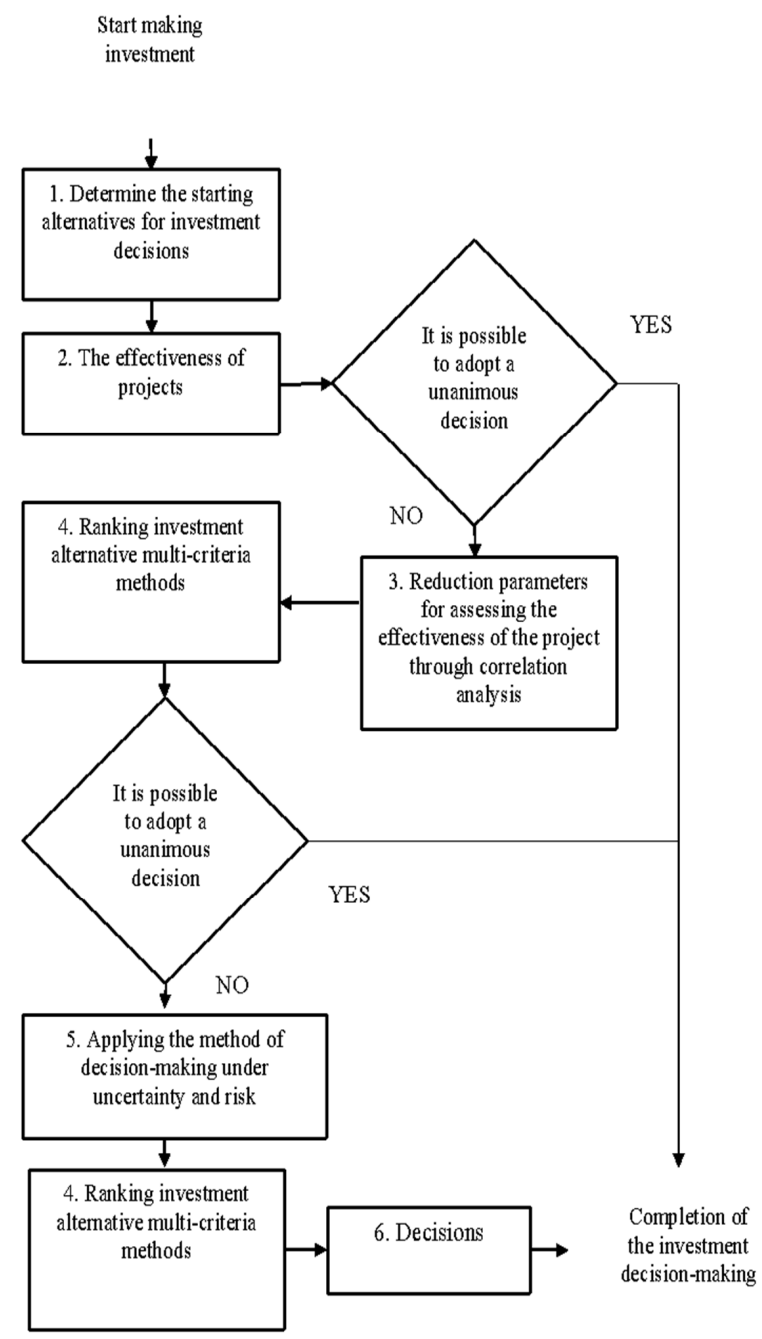

Figure 1. Model of the decision-making investment

\section{APPLICATION OF THE DECISION- MAKING MODEL}

When applying step 4 we need to do the following: 
- Determine the importance of each criterion according to which the alternatives will be ranked.

- Calculate the value according to different normalization.

- Apply methods of multi-criteria analysis for ranking the alternatives.

By applying the four steps we get results in terms of rank alternative order and based on that, we can make a decision on the selection of projects that best accomplish the goals set for the investment decisionmaking. The method of multi-criteria analysis is utilized to determine the rank order of alternatives. After that, the decisionmaker makes a compromise decision i.e. chooses an alternative which has the best rank.

Five different investment projects sourced from the $\mathrm{CB}$ Consulting Company Zenica whose activities include consulting and representing various companies as well as writing studies for various business ventures like wood briquettes, pellets, bowling alleys, IT technologies etc. will be used in order to demonstrate a model for investment decision-making in a practical way. All projects are connected to briquettes and pellets production in accordance to European Union directives. The project differences lie in the size of the companies that should be founded. This is considered because the same projects are used with the only difference between them being the size of the plant, number of the machines and equipment and employees. The basic goals of these projects are to explore and present the possibilities of commercial use of wood waste. The point of focus is determining the amounts of available wood waste and its best use in bio-renewable fuel production. The results of methods for evaluating the investment projects efficiency are shown in Table 1.

This table shows that each method for assessing the effectiveness of projects gives a different result. Therefore, it is very important, when making investment decisions, to take into account all the pros and cons of these methods. Having made the decision to use only one of these methods is very contentious and flawed since each of these methods has its advantages and disadvantages. When making an investment decision, it is necessary to include as many parameters and analysis as possible in order to comprehend all aspects of the investment decision-making process.

The NPV value of the projects is between 105256 and 424881 pecuniary units. The gained results show that every project is profitable because of the positive NPV value. The NPV criteria show that P1 has the best results while P5 has the worst. The IRR criteria are in the range between 19.33 at P1 that has the lowest value, and 23.30 at project P3, which is the highest IRR value. All IRR results show that every project is profitable. The PDP value shows that P1 has the shortest return

Table 1. Results and analysis of evaluating investment projects efficiency

\begin{tabular}{lccccccccc}
\hline & NPV & IRR & PDP & PI & ROR & ARR & CCF & MIRR & DPBP \\
\hline P1 & 424881 & 19.33 & 3.13 & 1.30 & 179.70 & 35.94 & 1115795 & 15.99 & 3.84 \\
P2 & 332860 & 21.55 & 3.42 & 1.37 & 188.87 & 37.77 & 799802 & 17.15 & 4.04 \\
P3 & 212634 & 23.30 & 3.21 & 1.42 & 195.49 & 39.10 & 477447 & 18.08 & 3.86 \\
P4 & 318858 & 22.91 & 3.36 & 1.46 & 204.52 & 40.90 & 731642 & 18.58 & 3.95 \\
P5 & 105264 & 20.39 & 3.59 & 1.40 & 203.33 & 40.67 & 268670 & 17.74 & 4.18 \\
\hline
\end{tabular}

Source: Survey results 
Table 2. Results of the project ranking order using the method for assessing the effectiveness of project(s)

\begin{tabular}{lccccccccc}
\hline & NPV & IRR & PBP & PI & ROR & ARR & CCF & MIRR & DPBP \\
\hline P1 & 1 & 5 & 1 & 5 & 5 & 5 & 1 & 5 & 1 \\
P2 & 2 & 3 & 4 & 4 & 4 & 4 & 2 & 4 & 4 \\
P3 & 4 & 1 & 2 & 2 & 3 & 3 & 4 & 2 & 2 \\
P4 & 3 & 2 & 3 & 1 & 1 & 1 & 3 & 1 & 3 \\
P5 & 5 & 4 & 5 & 3 & 2 & 2 & 5 & 3 & 5 \\
\hline
\end{tabular}

Source: Survey results

time with 3.13 years while P5 has the longest return time with 3.59 years. This criterion shows at which point of time the project becomes profitable, that is when the project's overall income become higher than the project's overall expenses. PI indicator is bigger than 1 which shows that all projects are efficient and that the current net income values surpass the initial investment. Project P4 shows the best results while project P1 shows the worst results at this criterion. The values gained for criterion ROR show that project $\mathrm{P} 4$ has the best results, while project P1 has the worst. However, all results are very good because they mark the investment return rate. ARR criteria show that the average value of all future net income starts at 35.94 at project $\mathrm{P} 1$ till 40.90 at project $\mathrm{P} 4$. The absolute value of CCF in its last year shows that the highest money flow value is at project P1 while the lowest is at project P5. The MIRR value shows that project $\mathrm{P} 4$ has the highest return rate while project $\mathrm{P} 1$ has the smallest return rate. The MIRR values are over $15.99 \%$ which represent a good value that can be higher than the reinvestment rate. DPBP as well as PDP show that project $\mathrm{P} 1$ has the shortest investment return time, meaning that the initial funds are returned first at this project, while project P5 has the longest investment return time.

By analyzing all criteria for all projects it can be concluded that all projects are efficient and that they enable a high return of initial investments and that they all represent a good choice for investors. However, an investment decision cannot be made on grounds of only one criterion because such a decision would be flawed and that is why as many criteria as possible should be included. Therefore, the projects have to be ranked based on certain criteria and the results can be conflicting.

Based on the results gained by assessing the effectiveness of the investment projects, each project shall be ranked by a certain criterion. P1 for example, has the best NPV values and is therefore ranked first, P2 as second, P4 as third, P3 as fourth and P5 as fifth. All projects are ranked this way, however, the lowest value for criteria PDP and DPBP are the best, and therefore the project that has the lowest values for this criterion shall be the best. This is how the rank presented in table 2 was formed.

Based on table 2, it is shown that the same rank ancestor can be found in NPV and CCF indicators, i.e. ROR and ARR indicators, PDP and DPBP indicators and PI and MIRR indicators. Indicators NPV and $\mathrm{CCF}$ take into account only the cash flow of the project and are linked as such. Then, ROR and RDA are a static assessment of efficiency for the investment project and do not take into account the discount factor. These indicators use the same information but they are placed in a different way in the relationship. For 
Table 3. Pearson correlation coefficient matrix for the initial decision

\begin{tabular}{lrrrrrrrrr}
\hline & NPV & IRR & PBP & PI & ROR & ARR & CCF & MIRR DPBP \\
\hline NPV & 1.00 & & & & & & & & \\
IRR & -0.22 & 1.00 & & & & & & & \\
PBP & 0.68 & 0.02 & 1.00 & & & & & & \\
PI & -0.56 & 0.84 & -0.40 & 1.00 & & & & & \\
ROR & -0.72 & 0.55 & -0.66 & 0.92 & 1.00 & & & & \\
ARR & -0.72 & 0.55 & -0.66 & 0.92 & 1.00 & 1.00 & & & \\
CCF & 0.99 & -0.36 & 0.68 & -0.66 & -0.78 & -0.78 & 1.00 & & \\
MIRR & -0.57 & 0.83 & -0.41 & 1.00 & 0.92 & 0.92 & -0.67 & 1.00 & \\
DPBP & 0.66 & 0.20 & 0.98 & -0.23 & -0.52 & -0.52 & 0.63 & -0.24 & 1.00 \\
\hline Source: Survey results & & & & & & & & &
\end{tabular}

PBP and DPBP indicators, it is said to be calculated in the same manner whereas only DPBP takes into account the discount factor. PI and MIRR indicators are using a discount factor, only in a different way. The discounting net income is made in the initial year and for MIRR it is made in the final year of the economic life of the project and all this is then divided by the initial investment.

If you take into account all the methods for assessing the effectiveness of the project, as it can be seen from the results, these related methods would increase their rank order. It is, therefore, necessary to carry out the reduction method. However, this should not be done without the correlation of these results because this kind of methodology shows the actual correlation (analysis) between these two methods.

Since there are many different types of correlation analysis in practice, Pearson correlation coefficient will be applied here. Pearson correlation coefficient compares the data from the column and looks closely at their interconnection. The value of the Pearson correlation coefficient ranges can vary or falls rom one to minus one. When the result is closer to one, the correlation of the observed phenomenon is higher and vice versa, the closer it is to zero the correlation is weaker or lower. If the result is negative, it represents the inverse correlation i.e. with the increase of one parameter the second parameter decreases and vice versa. Therefore, increasing of one parameter causes a drop in the second.

It should be noted that the PBP and DPBP indicators are preferable to have as small or low result as possible, i.e. to minimize these indicators while for others the opposite is true, i.e. the aim is to maximize these indicators. Therefore, it is necessary to make corrections of correlation analysis results for these indicators.

According to these results, we can clearly see that the strongest connection can be found in ROR and ARR methods and the result of their correlation is one, which shows complete unit cohesion. There is also a great connection in PI and MIRR indicators and the result of correlation analysis is almost one. Also, PBP and DPBP, along with NPV, are connected with CCF. Having these results in mind, it is possible to reduce the total number of methods for the assessment of the efficiency of the investment that is going to be utilized or used. Based on the connection between the indicators, we omit one method from each of these pairs. Therefore, here, based on the further analysis, the following indicators ARR, MIRR, PBP and CCF will be omitted 
because these indicators are less used in practice. This will help in avoiding a double impact on making the investment decision.

Using this analysis, it can be seen how it can lead to incorrect final decisions when making an investment decision based on only one method. Then, the investment decisions are based on a selection of an investment project which has the highest score, thereby ignoring other methods. It is, therefore, essential in making investment decisions to include all relevant methods and make a decision that represents a compromise of all the methods previously used. From these setup problems, it is evident that there are several criteria and several alternatives. Having this in mind, it can be concluded that this is a multi-criteria decision problem which can be solved by using a method for multi-criteria analysis.

In order to assess these projects through a multi-criteria analysis it is necessary to use the following steps:

- The first step - to calculate indicators of investment projects and based on these results a matrix of decision-making is formed;

- The second step - the normalization of data in order to obtain the uniform data;

- The third step - determining the weight coefficient for the indicators mentioned;

- The fourth step - the formation of ranking based on the results of the multi- criteria analysis method.

- $\quad$ The first step of this methodology has been developed and is presented in the table above based on which or from which we will omit the four methods for assessing the effectiveness of projects.

The second step is data normalization and this is the first step in using the multi-criteria analysis method. Normalization is done if the measurement scale for the criteria is not the same or comparable, the distance of each alternative based on which the ideal solution is calculated. Since the gained results are in different values, NPV are in pecuniary values, IRR and ROR are in percentage values, PI is in absolute values and DPBP is in years, in order to compare this, it is necessary to find a uniform measurement unit. The task of normalization is to correct the initial values into the uniform value so that they could be compared with each other. Although normalization is the first step in the project ranking it is not harmless because with the use of different types of normalization we get a different project rank order. In our example, we have a case where 4 parameters are maximized, i.e. it is preferable that their values are as high as possible (NPV, IRR, PI, and ROR) and one parameter is minimized i.e. it is preferable its value to be less and this is the parameter of time return on investment (DPBP). Taking this into consideration, the initial matrix of

Table 4. Decision-making matrix

\begin{tabular}{cccccc}
\hline & $\begin{array}{c}\text { NPV } \\
\max \end{array}$ & $\begin{array}{c}\text { IRR } \\
\max \end{array}$ & $\begin{array}{c}\text { PI } \\
\max \end{array}$ & $\begin{array}{c}\text { ROR } \\
\max \end{array}$ & $\begin{array}{c}\text { DPBP } \\
\min \end{array}$ \\
\hline P1 & 424881 & 19.33 & 1.30 & 179.70 & 3.84 \\
P2 & 332860 & 21.55 & 1.37 & 188.87 & 4.04 \\
P3 & 212634 & 23.30 & 1.42 & 195.49 & 3.86 \\
P4 & 318858 & 22.91 & 1.46 & 204.52 & 3.95 \\
P5 & 105264 & 20.39 & 1.40 & 203.33 & 4.18 \\
\hline
\end{tabular}

Source: Survey results 
decision making is formed and it is presented in Table 4.

Having determined which parameters should be maximized or minimized, it is necessary to determine the type of normalization that will be used. Papers written by Pavlicic (2002), Puska (2013) as well as other papers/works on this subject have shown that normalization plays a big role in the final ranking process. It is necessary to analyze in detail the initial decision matrix and the given criteria in order to assign appropriate normalization to be at their best when representing the criterion. Once you have selected indicators which will be used to observe investment projects it is necessary to evaluate them and determine their importance by using weighting factors. The purpose of weight coefficients is just preference criteria and the goal of normalization is to make correction data for better analysis in the best way possible. Normalized decision-making matrix results are presented in Table 5 .

Normalization that is commonly used in practice is:

- Vector normalization

- Linear normalization

- Percentage normalization

Normalization will show how important the selection is in the application of multicriteria analysis method because the normalization also depends on the order of alternatives. This paper will be using linear normalization which is calculated using the following formula:

$$
r_{i j}=\frac{x_{i j}-x_{r}^{* *}}{x_{j}^{*}-x_{j}^{* *}} ; r_{i j}=1-\frac{x_{i j}-x_{r}^{* *}}{x_{j}^{*}-x_{j}^{* *}}
$$

where $\mathrm{x} * \mathrm{j}$ - is the maximum value of the characteristics for a given criterion, and $\mathrm{x} * *$ $\mathrm{j}-$ is the minimum value of the characteristics for a given criterion.

The third step in the ranking of investment projects is the selection of weight ratio. Weights are usually numbers that are subjectively selected and their sum is equal to one. Weights are subjective preferences of decision-makers based on the relative knowledge on mutual significance criteria. For an investor, weights ratio represents subjective opinions on criteria and how important they are for decision-makers. He holds and assigns weights according to their personal preferences. Every investor has to decide what the best and most important criteria is and awards higher weight coefficients accordingly. To avoid personal judgment it is possible to use an objective method for determining the weight coefficients. "The best known objective methods are entropy method and the CRITIC method" (Milicevic \& Zupac, 2012). This paper will be using the CRITIC method.

The CRITIC method is used in order to

Table 5. Normalized decision-making matrix

\begin{tabular}{cccccc}
\hline & $\begin{array}{c}\text { NPV } \\
\text { max }\end{array}$ & $\begin{array}{c}\text { IRR } \\
\text { max }\end{array}$ & $\begin{array}{c}\text { PI } \\
\text { max }\end{array}$ & $\begin{array}{c}\text { ROR } \\
\text { max }\end{array}$ & $\begin{array}{c}\text { DPBP } \\
\text { max }\end{array}$ \\
\hline P1 & 1.00 & 0.00 & 0.00 & 0.00 & 1.00 \\
P2 & 0.71 & 0.56 & 0.44 & 0.37 & 0.42 \\
P3 & 0.34 & 1.00 & 0.80 & 0.64 & 0.95 \\
P4 & 0.67 & 0.90 & 1.00 & 1.00 & 0.69 \\
P5 & 0.00 & 0.27 & 0.67 & 0.95 & 0.00 \\
\hline
\end{tabular}

Source: Survey results 
determine weight values of objective criteria which include the intensity and contrast of the conflict inherent in the structure of the decision problem. It belongs to a class of correlation method and is based on analytical testing decision matrix in order to determine the information contained in the criteria by which to evaluate the variants. In order to determine the contrast criteria, a standard deviation of normalized criterion is used, as well as value variants, by columns and the correlation coefficients of all pairs of the columns.

The CRITIC method steps are:

- There is a complex linear normalization. Thus, the initial matrix is converted into a matrix with the generic elements $\mathrm{x}_{\mathrm{ij}}$.

- $\quad$ Each vector has a standard deviation $\sigma_{j}$, which represents a measure of deviation values of variants for a given criterion of some average values. Standard deviation is, in fact, the size which is still used in this method.

- Then, a symmetrical matrix of dimension $\mathrm{m} \times \mathrm{m}$ with elements $\mathrm{R}_{\mathrm{JK}}$ is constructed, which represents the coefficients of linear correlation vector $\mathrm{X}_{\mathrm{J}}$ and $X_{K}$. The greater the discrepancy between the criterion (value) for (criteria) variants $\mathrm{j}$ and $\mathrm{k}$, the lower the coefficient value RJK is. The Spearman correlation coefficient can be used instead of Pearson correlation coefficient.

$\sum_{k=1}^{m}\left(1-r_{j k}\right)$

The previous term is a measure of conflict criterion $\mathrm{j}$ in relation to the other criteria in the crucial situation (Milicevic \& Zupac, 2011).

- The subsequent evaluation of the amount of information $C_{j}$ which is contained or given in the criteria $\mathrm{j}$, therefore it is determined by the combination of the above size and $\sigma_{j} r_{j k}$ as follows:

$C_{j}=\sigma_{j} \sum_{k=1}^{m}\left(1-r_{k j}\right)$

The objective criteria weights are obtained by normalizing the size $\mathrm{C}_{\mathrm{j}}$; Weight results according to the CRITIC method are presented in Table 6.

The results gained with the CRITIC method show that NPV is the most significant criterion because it has the highest result dispersion. IRR is the least significant criterion because it has the lowest result dispersion. These results show that the criterion NPV will take part in the result with a share of $25 \%$ while the PI criterion will have a share of $15 \%$.

After having finished the previous three steps, the fourth step is to calculate the ranking order of projects using appropriate methods of multi-criteria analysis. First of all, the normalized values are multiplied with the weight coefficient and formulas for calculating ideal positive deviations and ideal negative solutions are then applied in the TOPSIS method. In the SAW method, the values of the weight data are added while the VIKOR method calculates the deviation from the biggest and smallest values of the alternatives. The results given by these methods show certain deviations or irregularities. In the VIKOR method, the normalization has no role in the final result because when calculating $R_{j}$ a formula that is the same as the formula for linear normalization is used.

Having applied the methods of multicriteria analysis, the decision-maker will choose the project that shows or provides the 
Table 6. Results of weight coefficients according to the CRITIC method

\begin{tabular}{lrrrrr}
\hline & NPV & IRR & PI & ROR & DPBP \\
\hline CRITIC & 0.25 & 0.15 & 0.16 & 0.22 & 0.22 \\
\hline \multicolumn{2}{l}{ Source: Survey results }
\end{tabular}

Table 7. Results of model investment

\begin{tabular}{ccccccc}
\hline & \multicolumn{2}{c}{ TOPSIS } & \multicolumn{2}{c}{ VIKOR } & \multicolumn{2}{c}{ SAW } \\
Alternative & Results & Rang & Results & Rang & Results & Rang \\
\hline P1 & $\mathbf{0 . 5 1 7 4}$ & $\mathbf{3}$ & $\mathbf{0 . 7 9 0 9}$ & $\mathbf{4}$ & $\mathbf{0 . 4 7 0 0}$ & $\mathbf{4}$ \\
P2 & $\mathbf{0 . 5 1 2 4}$ & $\mathbf{4}$ & $\mathbf{0 . 5 1 0 5}$ & $\mathbf{3}$ & $\mathbf{0 . 5 0 5 5}$ & $\mathbf{3}$ \\
P3 & $\mathbf{0 . 6 3 8 4}$ & $\mathbf{2}$ & $\mathbf{0 . 3 7 6 3}$ & $\mathbf{2}$ & $\mathbf{0 . 7 1 1 5}$ & $\mathbf{2}$ \\
P4 & $\mathbf{0 . 7 7 6 5}$ & $\mathbf{1}$ & $\mathbf{0 . 0 0 0 0}$ & $\mathbf{1}$ & $\mathbf{0 . 8 3 3 4}$ & $\mathbf{1}$ \\
P5 & $\mathbf{0 . 4 0 1 9}$ & $\mathbf{5}$ & $\mathbf{1 . 0 0 0 0}$ & $\mathbf{5}$ & $\mathbf{0 . 3 5 6 1}$ & $\mathbf{5}$ \\
\hline
\end{tabular}

Source: Survey results

best ranking order. In this case, it is a project $\mathrm{P} 4$, while the project P5 is the worst. Only when it comes down to projects $\mathrm{P} 1$ and $\mathrm{P} 2$, there is a different rank order in relation to the method used in multi-criteria analysis and in the TOPSIS method, while the same order of alternative methods is valid for VIKOR and SAW.

\section{DISCUSSION}

A model based on different MCDM methods was used in this paper. Five different investment projects connected to the production of briquettes and pellets, that were made available to us from $\mathrm{CB}$ Consulting Company Zenica, were used for the implementation of this model. Methods for investment assessment were used while choosing which project most appropriately realizes the research goal, starting the production of briquette or pellet.

Results gained by methods for investment assessment are quantitative indicators and that is why classic MCDM methods were used for project ranking. In contrast to classic MCDM methods, the focus today is on fuzzy methods that use quantitative and qualitative indicators or only qualitative indicators for project ranking. Hashemi et al. (2016), for example, used the ELECTRE III method for project ranking by using interval fuzzy logic. However, Polat et al. (2016) used quantitative indicators for projects and applied AHP and PROMETEE methods. The distinctiveness of the used model is that no subjective grades of criteria weight were used. The CRITIC method was used instead, for determining objective criteria weight. This is why the AHP method was not used, even though it was used in the previous study and in the following studies: Triantaphyllou i Mann (1995), Kumar (2006), Mahmoodzadeh et al. (2007), Amiri (2010), Pangsri (2015) and other studies. The mention authors used subjective criteria weight and that is why the applied the AHP method i.e. the ANP method by author Mohanty et al. (2005).

Because of the above mentioned the presented model used a combination of the CRITIC method and the TOPSIS, VIKOR and SAW methods. The reason for using these three methods is to show that the presented project can be used with every method. It is also possible to correct the model and to adapt it to determine the 
criteria weight with subjective grades and enable the use of the AHP method instead the CRITIC method.

The results gaind by applying this model cannot be compared to other approaches because different projects, criteria and the methods were used. This is yet another reason why three methods were used to compare the gained results. Based on the results it can be concluded that the ranking lists gained by the SAW and VIKOR methods is the same while they are different in the TOPSIS method. The difference is in project $\mathrm{P} 1$ and $\mathrm{P} 2$. Project $\mathrm{P} 1$ was ranked as fourth using the SAW and VIKOR method, while project $\mathrm{P} 2$ was ranked third. By applying the TOPSIS method this ranking is reversed and project $\mathrm{P} 1$ is ranked third and project $\mathrm{P} 2$ is ranked fourth. The other project kept their ranking regardless of the method used.

\section{CONCLUSION}

When making investment decisions, it is preferable that this decision is made by using a number of methods for evaluating the effectiveness of investment and if it is not possible to come to a unique solution then there should be a compromise. A compromise solution is one that does not require that a project is the best in all indicators because that is not possible. It is therefore requested that the project as a whole shows the best results in comparison to other projects and at the same time a compromise is what is sought.

The generated model showed how to both efficiently and effectively make investment decisions. In this model, the synthesis method for assessing the effectiveness of investment projects using multi-criteria analysis methods was carried out. This model represents a new approach in dealing with the investment decision because a combination of multiple approaches is made and it raises the problem of choosing investment project that gives the best results in comparison to other investment projects. On that occasion, not only a detailed analysis of how companies make daily investment decisions is done but also the way of making those decisions.

In this paper, the principle of ranking investment alternatives has been applied in order to make investment decisions. It is the ranking investment alternatives that are possible by using methods of multi-criteria analysis. The characteristics of multi-criteria analysis methods and their application make it possible that after having calculated the value of all the methods they are systematized and the rank of investment alternatives is formed. On a practical example that was used in this study, project P4 provided the best result, while the project P5 achieved the worst result. The implementation of this model in the practical example has shown that it is applicable in practice.

During the implementation of this model it is necessary to determine in future studies what is the impact of particular methods for assessing the effectiveness of investments that are not used, as well as those methods that were used in this paper and it is necessary to determine which indicators accomplish, in the best way possible, the investment goals that were set. Implementing the methods for multi-criteria analysis, a major role in assessing the outcome or a result is ensured by or belongs to the used normalization data along with weights coefficient. In the following or future papers, it is necessary to examine how 


\title{
МОДЕЛ ДОНОШЕЊА ИНВЕСТИЦИОНЕ ОДЛУКЕ ПОМОһУ МЕТОДА ВИШЕКРИТЕРИЈСКЕ АНАЛИЗЕ
}

\author{
Адис Пушка, Адмир Бегановић и Сеад Шадић
}

\begin{abstract}
Извод
Приликом доношења инвестиционе одлуке инвеститору стоји на располагању више алтернативних инвестиција. Задатак инвеститора је да одабере ону инвестицију која ће му на најбољи начин реализовати циљеве инвестиција. За могуће инвестиције се најчешће прави плански докуменат у облику инвестиционог пројекта. Да би се одабарала она инвестиција која најбоље задовољава циљеве инвестиција потребно је исте вредновати. За вредновање инвестиција инвеститору стоје на располагању методе за оцјену ефикасности инвестиција. Резултати које дају ове методе обично су у конфликту што отежава доношење инвестиционе одлуке инвеститору.

У овом раду је представљен модел доношења инвестиционе одлуке помоћу метода вишекритеријске анализе. Пошто су резултати метода за оцјену ефикасности инвестиција различити да би се донијела одлука потребно је уважити што више критерија како би се донијела што боља одлука. Управо задатак овога модела је да се примјени више метода за оцјену ефикасности инвестиција те помоћу метода за вишекритеријску анализу изврши рангирање потенцијалних инвестиционих пројекат, те на тај начин донесе одлука која на најбољи начин задовољава циљева инвестирања.
\end{abstract}

Кључне речи: инвестициони пројекти, доношење инвестиционе одлуке, методе за оцјену ефикасности инвестиција, методе вишекритеријске анализе

individual data normalization has a role in investment and provides conclusions which are best for this decision-making process. In addition, it is necessary to examine, in future operations, the application of different objective methods for determining the weight coefficient, and the use of other methods for multi-criteria analysis in this model. It is also necessary to upgrade this model in future research and to include different criteria so that other fuzzy logic methods could be used. Overall, in the future papers, it is necessary to determine what the methods are for assessing the effectiveness of investments most suitable for this decision problem, which normalization is the most suitable and which method for determining the weight method is the most suitable when applying this model in practice. This would facilitate the implementation of this model in practice.

\section{References}

Amiri, M.P. (2010). Project selection for oil-fields development by using AHP and fuzzy TOPSIS method. Expert systems with applications, 37 (9), 6218-66224.

Aragonés-Beltrán, P., ChaparroGonzález. F., Pastor-Ferrando J.-P., \& PlaRubio, A. (2014). An AHP (Analytic Hierarchy Process)/ANP (Analytic Network Process)-based multi-criteria decision 
approach for the selection of solar-thermal power plant investment projects. Energy, 66 (1), 222-238.

Bendeković, J. (1993). Planning of investment projects. Book III, Zagreb: The institute of economics. (in Croatian)

Bukumirović, M., \& Čupić, A. (2005). Evaluation of the characteristics of the postal center infrastructure. PosTel 2005, 315-324. (in Serbian)

Ehrhardt, M.C., \& Brigham, E.F. (2011). Corporate Finance: A Focused Approach. Fourth Edition, Mason, $\mathrm{OH}$ : South-Western Cengage Learning.

Fabozzi, F.J., \& Drake, P.P. (2010). The Basics of Finance, Hoboken. New Jersey: John Wiley \& Sons.

Fabozzi, F.J., \& Peterson, P.P. (2003). Financial Managment and Analysis. Second Edition, Hoboken N.J.: John Wiley \& Sons.

Hashemi, S. S., Razavi Hajiagha, S. H., Zavadskas, E. K., \& Mahdiraji, H. A. (2016). Multicriteria group decision making with ELECTRE III method based on intervalvalued intuitionistic fuzzy information. Applied Mathematical Modelling, 40 (2), 1554-1564.

Jeremić, Lj. (2008). Fundamentals of finance. Belgrade: Singidunum University. (in Serbian)

Jovanović, P. (2006). Investment management. Sixth edition. Belgrade: Faculty of Organisational Sciences. (in Serbian)

Ključnikov, A., Belás, J., Kozubíková, L., \& Paseková, P. (2016). The Entreprenurial Perception of SME Business Environment Quality in the Czech Republic. Journal of Competitiveness, 8 (1), 66-78.

Krčmar, M. (2002). Financial maths and investment decision making methods. Sarajevo: Kemigrafika-Trade. (in Bosnian)

Kumar, S. (2006). Integrated project evaluation and selection using multipleattribute decision-making technique. International Journal of Production Economics, 103 (1), 90-103.

Lu, J., Zhang, G., \& Ruan, D. (2007). Multi-Objective Group Decision Making Methods, Software and Applications with Fuzzy Set Techniques. London: Imperial College Press.

Mahmoodzadeh, S., Shahrabi, J., Pariazar, M., \& Zaeri, M. S. (2007). Project selection by using fuzzy AHP and TOPSIS technique. World Academy of Science, Engineering and Technology, 30, 333-338.

Manteghi, N., \& Haddadpour Jahromi M.J. (2012). Innovative model to priority distributed generation technology. Procedia Technology, 1, 485-489.

Milićević, R.M., \& Župac, Ž.G. (2012). An Objective Approach to Determining Criteria Weights. Vojnotehnički glasnik, 60 (1), 39-56. (in Serbian)

Mohanty, R.P. (1992). Project selection by a multiple-criteria decision-making method: an example from a developing country. International Journal of Project Management, 10(1), 31-38.

Mohanty, R.P., Agarwal, R., Choudhury, A.K., \& Tiwari, M.K. (2005). A fuzzy ANPbased approach to R\&D project selection: a case study. International Journal of Production Research, 43 (24), 5199-5216.

Nićin, N., \& Pušara, N. (2010). Investment management. Belgrade: Belgrade Business School - Higher Education Institution for Applied Studies. (in Serbian)

Orsag, S. (2002). Capital budgeting estimation of investment projects. Zagreb: Masmedia. (in Croatian)

Pangsri, P. (2015). Application of the Multi Criteria Decision Making Methods for Project Selection. Universal Journal of Management, 3 (1), 15-20. 
Pavličić, D. (2002). Consistency of choice of the method of multi-factor analysis. Ekonomski anali, 44 (155), 59-82. (in Serbian)

Polat, G., Damci, A., Pelin Gurgun, A., \& Demirli, I. (2016). Urban Renewal Project Selection Using the Integration of AHP and PROMETHEE Approaches. Procedia Engineering, 164, 339-346.

Puška, A. (2011). Sensitivity analysis in the function of investment decision making. Praktični menadžment, 2 (3), 80-86. (in Bosnian)

Puška, A. (2012). Making investment decisions using the TOPSIS method. EMC Review, 2 (3), 143-160. (in Bosnian)

Puška, A. (2013). Normalization of data and its impact on the ranking of investment projects. Poslovni Konsultant, 5 (22), 30-41. (in Bosnian)

Radojičić, M., \& Vesić, J. (2003) One approach to modeling and expressing preferences in multi-criteria optimization. Menadžment u industriji, Book of Proceedings, 241-246. (in Serbian)

Ross, S., Westerfield, R., \& Jaffe, J. (2002). Fundamentals of Corporate Finance, Sixth Edition, Alternate Edition, New York: McGraw-Hill.

Srđević, B, Srđević Z., \& Zoranović T. (2002). PROMETHEE, TOPSIS AND CP in multi-criteria decision-making in agriculture. Letopis naučnih radova, 26 (1), 5-23. (in Serbian)

Srđević, B. (2002). Multiple criteria for the purpose of acoustics. Vodoprivreda, 34 (1-6), 35-45. (in Serbian)

Srđević, B. (2005). Discrete decision models in optimizing the use of the canal network in Vojvodina. Letopis naučnih radova Poljoprivrednog fakulteta, 29 (1), 1930. (in Serbian)

Triantaphyllou E. (2000). Multi-criteria decision making methods: a comparative study, Massachusette: Kluwer Academic Publishers, Norvell.

Triantaphyllou, E., \& Mann, S.H. (1995). Using the Analytic Hierachy Process for decision making in engineering applications: some challenges. International Journal of Industrial Engineering: Applications and Practice, 2 (1), 35-44.

Van Horne, J.C. \& Wachowich, J.M. Jr. (2002). Basic of financial management. 9th edition, Zagreb: Mate.

Vernimmen, P. (2009). Corporate Finance: Theory and Practice. Second Edition, Hoboken N.J.: John Wiley \& Sons.

Vidučić, Lj. (2006) Financial Management, Fifth Edition. Zagreb: RRIF plus. (in Croatian)

Volarević, H., \& Davosir Pongrac, D. (2010a). Capital budgeting Part III. Finansijski propisi i praksa, 16 (9), 57-66. (in Croatian)

Volarević, H., \& Davosir Pongrac, D. (2010b). Capital budgeting Part IV. Finansijski propisi i praksa, 16(10), 65-72. (in Croatian)

Yoon, K.P., \& Hwang, C-L. (1995). Multiple attribute decision making: an introduction. London: Sage Publications. 